\title{
SEMANTICS ANALYSIS OF SLANG (SAOS) IN SOCIAL MEDIA OF MILLENNIAL GENERATION
}

\author{
Tri Indah Rezeki ${ }^{1}$, Rakhmat Wahyudin Sagala ${ }^{2}$ \\ trindah.rizky@gmail.com
}

\author{
Prodi Pendidikan Bahasa Inggris, STKIP Budidaya Binjai \\ Prodi Pendidikan Bahasa Inggris, Universitas Muhammadiyah Sumatera Utara
}

\begin{abstract}
Abstrak
Setiap generasi pada zamannya akan menciptakan bahasa mereka sendri tidak terkecuali generasi milenial. Tujuan dari penelitian ini adalah menggambarkan fenomena analisis semantik dari bahasa slang yang digunakan generasi milenial di sosial media. Penelitian ini menginvestigasi; (1) jenis bahasa slang yang digunakan generasi milenial di sosial media; (2) bagaimana arti dari bahasa slang yang digunakan generasi milenial di sosial medial; (3) mengapa generasi milenial menggunakan bahasa slang di sosial media. Penelitian ini menggunakan metode deskriptif kualitatif untuk memperoleh data dari tuturan mahasiswa Universitas Islam Negeri Sumatera Utara (UINSU) sebagai generasi milenial dalam sosial media seperti Facebook dan Instagram. Data diperoleh dari observasi, wawancara dan dokumentasi. Dari hasil data, ditemukan bahwa dari 40 mahasiswa UINSU menggunakan bahasa slang didalam tuturan mereka di sosial media yaitu 33 yang menggunakan bahasa slang di Facebook dan 31 yang menggunakan bahasa slang di Instagram. Adapun jenis bahasa slang yang digunakan seperti fresh and creative, flippant, imitative, acronym dan clipping. Berdasarkan wawancara diketahui bahwa generasi milenial menggunakan bahasa slang di sosial media karena beberapa alasan seperti untuk menyapa, untuk memulai percakapan santai, untuk mengekspresikan kesan, dan untuk menunjukkan keakraban.
\end{abstract}

Kata Kunci: Slang, Jenis Bahasa Slang, factor alasan menggunakan Bahasa Slang, Generasi Milenial.

\section{Abstract}

Generation were born in every era eventually create their own language not least the latest generation commonly called the millennial generation. Specifically, the aim of our work broadens current knowledge of the phenomenon of Semantics Analysis of Slang (SAOS) in Social Media of Millennial Generation. This study investigated: 1) classification of SAOS used by millennial generation in social media; 2) how the meaning of SAOS used by millennial generation in social media; 3) why millennial generation used SAOS in social media. This study applied descriptive qualitative research in order to reveal the data from the discourse of English Department students at Universitas Islam Negeri Sumatera Utara in social media such as Facebook and Instagram and it was obtained from observation, interview and documentation. The data showed that millennial generation used slang language in their communication in social media namely 33 slang languages in Facebook and 31 slang languages in Instagram. Types of slang were fresh and creative, flippant, imitative, acronym and clipping. Millennial generation used SAOS in their social media because some reasons such as to address, initiate relax conversation, express impression and show intimacy.

Keywords: slang, classification of slang, reasons of using slang, millennial generation.

\section{INTRODUCTION}

For decades, millennial generations have always been the ones to establish language shifts. They may do it as a way to concrete a generational identity, or as a way to gain power in a situation when they don't typically have it. It is clear that the millennial generations entering the workforce has different communication experiences, and companies are beginning to see the results incorporated into workrelated communication methods. At the present, a unique challenge also creates new opportunities for using a variety communication approaches. Millennial generations are accustomed to communicate using various social media such as WhatsApp, BlackBerry Messenger, Instagram and also Facebook and YouTube.

Language is widely considered to be the most essential communication instrument to convey information. Language is one of important thing in human life because people can communicate each other easily through a language (Sagala,, 2019). Remarkably, a feature of language meaning is not only related to the words selections, but also how the way to convey it. When the speaker cannot convey his/her message by using one language, the speaker needs to change the language to be more understood (Sagala, Rakhmat, Rezeki, Gurning, 2018). Therefore, millennial 
generation tend to use more than one language as a necessity in society (Rezeki, 2018). Nowadays, slang has been a phenomenon in millennial generation era, not only for them who live in a city but also for them who live in villages have known slang language as if it has been a trend in the millennial era. While on the other hand, parents and adults complained about the grammar and speech of their children's language, which was challenging to be understood.

In formal situation such as in educational environment, we usually use the standard language. In contrast, in informal situation such as in the society or in one community, people usually use nonstandard language. One of non-standard language for which is found is slang. Hornby (1974) explains that slang refers to words, phrases, meanings of words, commonly used in talk among friends or colleagues, but not suitable for good writing or formal occasions. Slang is language (words, phrases, and usages) of an informal register that members of special groups like teenagers, musicians, or criminals favour in order to establish group identity. Slang is usually popular among millennial generation.

Millennial generation often used slang in daily life conversation. According to Merriam-Webster Dictionary, the millennial generation generally refers to the generation of people born between early 1980s and 1990s. The phenomenon of using slang by millennial generation happened in their daily communication in social media like chatting in Facebook, WhatsApp, direct messanger etc. In fact, when millennial generation use slang in their communication, some of them do not really understand the meaning of the slang word itself. They usually used slang because of hearing other people or getting influence from movie or songs. Millennial generation nowadays tend to use slang language which affect language shift for Indonesia people.
By developing slang language, it makes possible that the next generation are not able to know and to use Indonesia as a standard language. It means that the development of Indonesia language is very bad for millennial generation. In communication, the role of language is very important because the information which is conveyed need language. The meaning of language is not only related to the choice of words but also how the way to convey it. Today, millennial generation especially teenagers prefer to use slang language than formal language. Based on observation, the slang language is more comfortable for them to be used in daily conversation like chatting in Facebook, WhatsApp, direct messanger etc. Therefore, the goal of this study identified the phenomenon of semantics analysis of slang (SAOS) in social media of millennial generation, classification of slang used by millennial generation in social media; the meaning of slang used by millennial generation in social media and reasons why millennial generation used slang in social media.

\section{REVIEW OF LITERATURE}

\section{Slang}

Holmes (2001) states that people in a society may speak some varieties of language in accordance with different social situation they meet. It is true that people should know whether they are in informal or formal situation. When people speak, it is important in choosing appropriate language that will be used, formal style or informal one.

Slang is the informal language which is used in a particular group of people especially used by millennial generation in their activities to communicate each other. Munro cited in Fasola (2012) describes slang refers to non-standard language of words and expressions used in conversation or a letter, but it is not used in a speech or formal essay. In addition, people used slang to change the inelegant 
statement of being associated with foreigner or criminals, sometimes they use it to make jokes and to keep the secret of the word's meaning and also people want to express idea using another language besides the Standard English (Hanggoro, 2011).

Slang is the non-standard use of words in a language and it is categorized as a part of language in a society. According to Anderson and Trudgill in Ismail (2014), slang is not language or dialect, it can be said as a code that product by changing the existing language to the common one. Every language has a vocabulary, pronunciation, and grammar, whereas slang has not. It just has vocabulary which is not profanity and ungrammatical.

The form of slang can be a whole sentence but usually slang is categorized as a word. Slang itself can be described as deviating away from standard language use. Slang is a kind of non-standard use of words in a language and sometimes the creation of new words are from another language. The spreading of slang is very fast, especially among millennial generation. It is caused by the influence of media such as television, radio, internet, etc.

This issue had been analyzed and researched by many researchers with different focuses. Therefore, many findings had been already published in society.

First, Trimastuti (2017) found that slang language that used in talk between teenagers can be understood by certain group particularly group who use 'alay' language. 'Alay' language for communication has many errors in Bahasa Indonesia. Alay language in social media can be minimized in order to avoid misunderstanding in delivering message. Second, Pradianti (2013) concluded that slang words are frequently used among teenagers, have their own words to be used when interacting with their friends and slang words are a marker of teenagers' identity in their conversation style. Third, Amir (2017) indicated that slang language used by students of English Education Department in their daily conversation were slang in theater, art slang, public school or university slang as well as society slang. Besides, the male and female slang language was different caused of some factors such as situation and condition, age and politeness, as well as gender itself. To compare these studies, the main concern of my study was focused on the use of slang language used by millennial generation in social media especially in their communication in Facebook and Instagram. It emphasized five types of slang, the meaning of slang language and the reason why they used it in their social media.

\section{Classification of Slang}

Allan and Burridge (2006) classified the slang into five namely fresh and creative, flippant, imitative, acronym, and clipping.

1. Fresh and creative

It means that slang word has new vocabularies in order to describe something in informal situation. For example the word "mom" is used to address a woman, especially the elder one.

\section{Flippant}

It means that slang word consists of two words or more which does not have correlation with the denotative meaning. For example, break a leg which is means good luck for an actor.

3. Imitative

Imitative means that the slang word imitating or derived from the Standard English word; using the Standard English words in different meaning or combining two different words. The example is gonna. This is the slang word that derived from the phrase words "going to". The slang word "gonna" is commonly used by almost all of the people in the world.

\section{Acronym}

It means that the result of the word comes from first letter of each word in a phrase or using initials from a group of 
words or syllables and pronounce them as a new word. For example, NATO is the acronym of "North Atlantic Treaty Organization".

\section{Clipping}

It means that slang word comes from deletion of some part of longer word becomes a shorter form in the same meaning. For example, "till" refers to "until".

\section{Reasons of Using Slang}

Allan and Burridge (2006) investigated seven reasons of using slang. They are:

\section{a. To Address}

The speaker uses a slang word to address another speaker so that they can maintain their close relationship. People who have close relationship prefer to use informal address than formal one.

For example:

Man : Honey, I wouldn't go if I didn't have the most trustworthy man I know to look after my family

Woman : Oh, no. Not in my house.

In this conversation the slang word "honey" is used to address to beloved person. The man use the word to address the woman because she is the special person for him.

b. To Initiate Relax Conversation

People have tendency to use slang word in order to initiate relax conversation so that they have smooth conversation in formal situation. People who have close relationship with other tend to use certain words in order to make the conversation run more relaxed and comfortable.

c. To humiliate

Sometimes people use slang to express unpleasant or dislike feeling of other people by mocking them.

d. To form intimate atmosphere

People prefer to use slang word rather than formal word to form intimate atmosphere in order to show close relationships. When the speaker gets intimate with someone, it can mean that he is sexually involved. e. To express impression

People usually use slang word to express impression. It means when the speaker uses a slang word, he wants someone remember and feel impressed about their conversation. The use of slang gives impression to in group intimacy and solidarity.

f. To reveal anger

The use of slang word to reveal anger in order to make his anger sounds politely.

g. To show intimacy

The speakers use a slang word to show intimacy. It means they try to make their own conversation similar to that of the listener. They change to the language they believe the listeners would prefer to speak.

\section{Millennial Generation}

Fries (2017) states that millennial generation is the generational demographic cohort following

Generation $\mathrm{X}$. It also known as Generation Y. There are no precise dates for when this cohort starts or ends. Typically, millennial generation were born the early 1990 s to the mid- 2000s. Millennial generation have various characteristics depending on social and economic conditions. The generation is generally marked by an increased use and familiarity with communications, media, and digital technologies.

\section{METHOD}

This research applied a descriptive qualitative to analyze the data because it gives description of a problem. The qualitative research is used to investigate the social phenomenon (Trochim and William, 2006). Bogdan and Taylor (1992) explain that descriptive qualitative is one of the research procedures which produce descriptive data in form of speech and the behaviour of those being observed. For 
this case, Bogdan and Biklen (1992) recommended the characteristic of qualitative research has the natural setting and the researcher as a key instrument. It means that the researcher is as actor to collect the data (Moleong, 2005).

The data which is obtained in this research is the types, meanings and reasons of slang used by millennial generation in social media. The subjects of research were students in the English Department at Universitas Islam Negeri Sumatera Utara who were active in social media especially in Facebook and Instagram. The number of students was fifty students. The data were taken from students' discourse in Facebook and Instagram such as how they wrote their captions or their stories which contain semantics analysis of slang (SAOS). The data was obtained by transcribing the discourse of millennial generation in Facebook and Instagram.

In collected the data, researchers used instruments namely observation, interviews, and documentation and to check the data validation, the triangulation was used in this research by combining the information from both the discourse of millennial generation in social media and the techniques of data collection, i.e. documentation and interview.

\section{RESULT AND DISCUSSION}

\section{Classification and Meaning of SAOS used by Millennial Generation in Social Media}

Allan and Burridge (2006) classified five classifications of slang namely fresh and creative, flippant, imitative, acronym and clipping. Based on the data, the millennial generation used these types in their social media. Based on the data observation (appendix 1 and appendix 2), the percentage of types of slang used millennial generation in Facebook and Instagram was shown in table 1.1.

\begin{tabular}{|c|c|c|c|c|}
\hline No. & $\begin{array}{l}\text { Social } \\
\text { Media }\end{array}$ & $\begin{array}{c}\text { Types of } \\
\text { Slang }\end{array}$ & Total & Percentage \\
\hline \multirow{5}{*}{1.} & \multirow{5}{*}{ Facebook } & $\begin{array}{l}\text { Fresh and } \\
\text { creative }\end{array}$ & 12 & 36 \\
\hline & & Flippant & - & - \\
\hline & & Imitative & 3 & 10 \\
\hline & & Acronym & 14 & 42 \\
\hline & & Clipping & 4 & 12 \\
\hline \multirow{5}{*}{2.} & \multirow{5}{*}{ Instagram } & $\begin{array}{l}\text { Fresh and } \\
\text { creative }\end{array}$ & 14 & 45 \\
\hline & & Flippant & 1 & 3 \\
\hline & & Imitative & 1 & 3 \\
\hline & & Acronym & 14 & 45 \\
\hline & & Clipping & 1 & 3 \\
\hline
\end{tabular}

\section{Reasons of Using SAOS by Millennial Generation}

Allan and Burridge (2006) investigated seven different reasons of slang. They are to address, to initiate relax conversation, to humiliate, to form intimate atmosphere, to express impression, to reveal anger, to show intimacy. Based on interview to the students who use slang in their social media, most reasons why millennial generation use slang in their social media are to address, to initiate relax conversation, to express impression and to show intimacy.

Because of my study focused on five types of slang by Allan and Burridge (2006) namely fresh and creative, flippant, imitative, acronym and clipping, how the meaning of slang and why millennial generation used slang in their communication in Facebook and Instagram, it was exactly that these findings were different with the previous studies. First, Trimastuti (2017) focused on meaning of slang language which was analyzed into 4 namely grammatical meaning, lexical meaning, textual meaning and situational meaning. Second, Pradianti (2013) analyzed slang language through morphological processes namely coinage, borrowing, compounding, blending, clipping, back formation, acronyms, derivation, multiple process, Onomatopoeia, and reduplication. Third, 
Amir (2017) focused on the differences between male and female in using slang language of students of English Education Department students in their daily conversation in theater, art slang, public school or university.

\section{CONCLUSION}

Slang is the informal language which is used in a particular group of people especially used by millennial generation in their activities to communicate each other. Based on data which have been obtained from observation and interview, millennial generation used slang in their social media such as Facebook and Instagram. This phenomenon tends to make millennial generation as the next generation do not develop Indonesia language in the future because they are accustomed to use slang language than Indonesia language. Consequently, the existence of Indonesia language is endangered.

\section{DAFTAR PUSTAKA}

Allan, K., Burridge, K. 2006. Forbidden Words: Taboo and The Cencoring of Language. Cambridge: CUP

Amir, K. 2017. Gender Analysis on Slang Language in Students Daily Conversation. ETERNAL (English, Teaching, Learning and Research Journal). Fakultas Tarbiyah dan Keguruan UIN Alauddin. P. 229- 243. ISSN Print : 2477-4766 ISSN Online : $2580-5347$.

Bogdan and Biklen. 1992. Qualitative Research for Education: An Introduction to Theory and Method. Boston: Allyn and Bacon Inc.

Fasola, Jelena. 2012. Slang and Its history. United States

Fries, Kimberly. 2017. 5 Reasons Why Milleneal Leaders Need Performance Feedback. Fobes: USA

Hanggoro, Ari. 2011. An Analysis of Slang Terms in the American Gangster, a movie directed by Ridley Scott. Thesis: English Letters Department, Faculty of Adab and Humanities, State Islamic University Syarif Hidayatullah Jakarta

Holmes, Janet. 2001. An Introduction to Sociolinguistics. London: Longman

Hornby, A.S.1974. Oxford Advanced Learner Dictionary. London

Ismail, G. 2014. An Analysis of Subtitling Strategies of Idiomatic Expressions in the Film Entitled "The Avengers". Universitas Pendidikan Indonesia

Moleong, L.J. 2005. Metodologi Penelitian Kualitatif. Bandung: Remaja Rosdakarya

Pradianti, W. The Use of Slang Words Among Junior High School Students in Everyday Conversation (A case study in the ninth grade students of a junior high school in Bandung). Jurnal UPI Education. P.87-98.

Rezeki, Tri Indah. "Kontekstual Code Switching Dalam Seminar Proposal Program Studi Pendidikan Bahasa Inggris." Jurnal Serunai Bahasa Inggris 10.2 (2018): 1-7.

Sagala, Rakhmat Wahyudin, Tri Indah Rezeki, and Busmin Gurning. "Grammatical and Contextual Code Switching in the English Department Proposal Seminar." 3rd Annual International Seminar on Transformative Education and Educational Leadership (AISTEEL 2018). Atlantis Press, 2018.

Sagala, Rakhmat Wahyudin. "LANGUAGE ACQUISITION PADA ANAK PERIODE LINGUISTIK." (2019): 84-89.

Trimastuti, W. 2017. An Analysis of Slang Words Used in Social Media. Jurnal Dimensi Pendidikan dan Pembelajaran. P. 64-68. ISSN 25-27-7049

Trochim and William M.K. 2006. Descriptive Statistics. Research Methods Knowledge Base. Retrieved March 14th2011. 


\section{Appendix 1}

\section{Table 1.1. SAOS of Millennial Generation in Facebook}

\begin{tabular}{|c|c|c|c|c|c|c|c|}
\hline \multirow[b]{2}{*}{ No. } & \multirow[b]{2}{*}{ Discourse } & \multicolumn{5}{|c|}{ Types of SAOS } & \multirow[b]{2}{*}{ Meaning } \\
\hline & & $\begin{array}{l}\text { Fresh and } \\
\text { creative }\end{array}$ & Flippant & Imitative & Acronym & Clipping & \\
\hline 1. & $\begin{array}{l}\text { Terciduk abang } \\
\text { terheran-heran }\end{array}$ & $\sqrt{ }$ & & & & & Ketahuan \\
\hline 2. & Seafood mantul & & & & $\sqrt{ }$ & & $\begin{array}{l}\text { Mantap } \\
\text { betul }\end{array}$ \\
\hline 3. & $\begin{array}{l}\text { Walaupun } \\
\text { sudah lewat tapi } \\
\text { tetap bahagia. } \\
\text { Maacih }\end{array}$ & & & & & $\sqrt{ }$ & $\begin{array}{l}\text { Terimaka } \\
\text { sih }\end{array}$ \\
\hline 4. & $\begin{array}{l}\text { Ah, kurasa dulu } \\
\text { aku macam adik } \\
\text { tiri baginya, } \\
\text { selalu marah- } \\
\text { marah, parah } \\
\text { gaiss }\end{array}$ & & & $\sqrt{ }$ & & & $\begin{array}{l}\text { From guy } \\
\text { or guys } \\
\text { means } \\
\text { teman, } \\
\text { kawan }\end{array}$ \\
\hline 5. & $\begin{array}{l}\text { Octopus } \\
\text { (Gurita) sensai } \\
\text { tentakel nya itu } \\
\text { loh kenyal } \\
\text { kenyal endess }\end{array}$ & $\sqrt{ }$ & & & & & $\begin{array}{l}\text { Enak, } \\
\text { lezat }\end{array}$ \\
\hline 6. & $\begin{array}{l}\text { Copas dari } \\
\text { sebelah }\end{array}$ & & & & $\sqrt{ }$ & & $\begin{array}{l}\text { Copy } \\
\text { paste }\end{array}$ \\
\hline 7. & $\begin{array}{l}\text { Tadi nyempetin } \\
\text { ngasi materi } \\
\text { dikit ples wefie- } \\
\text { wefie }\end{array}$ & & & & $\sqrt{ }$ & & We selfie \\
\hline 8. & $\begin{array}{l}\text { Bismillah, Otw } \\
\text { Kisaran }\end{array}$ & & & & $\sqrt{ }$ & & $\begin{array}{l}\text { On The } \\
\text { Way }\end{array}$ \\
\hline 9. & $\begin{array}{l}\text { Yuk ngerujak } \\
\text { brayy }\end{array}$ & & & $\sqrt{ }$ & & & $\begin{array}{l}\text { From } \\
\text { brother } \\
\text { means } \\
\text { saudara / } \\
\text { rekan }\end{array}$ \\
\hline 10. & $\begin{array}{l}\text { Yuk order ya } \\
\text { bunsay minat } \\
\text { inbox }\end{array}$ & & & & $\sqrt{ }$ & & $\begin{array}{l}\text { bunda } \\
\text { sayang }\end{array}$ \\
\hline 11. & $\begin{array}{l}\text { Alhamdulillah } \\
\text { pagi-pagi sudah } \\
\text { dapat berkah. } \\
\text { Yuk kepoin toko } \\
\text { L\&F }\end{array}$ & $\sqrt{ }$ & & & & & $\begin{array}{l}\text { Ingin } \\
\text { tahu } \\
\text { segala } \\
\text { hal }\end{array}$ \\
\hline 12. & $\begin{array}{l}\text { Kata bocah- } \\
\text { bocah ini } \\
\text { mamak inces }\end{array}$ & & & & & $\sqrt{ }$ & Princess \\
\hline 13. & $\begin{array}{lr}\text { Sekarang } & \text { gak } \\
\text { perlu } & \text { ribet } \\
\text { kalau } & \text { anak tiba- } \\
\text { tiba } & \text { demam, } \\
\text { panas, } & \text { batuk } \\
\text { pilek } & \\
\end{array}$ & $\sqrt{ }$ & & & & & $\begin{array}{l}\text { Repot, } \\
\text { rumit }\end{array}$ \\
\hline 14. & $\begin{array}{l}\text { Only 1000/foto } \\
\text { ya say. }\end{array}$ & & & & & $\sqrt{ }$ & Sayang \\
\hline 15. & Kuy & $\sqrt{ }$ & & & & & Yuk \\
\hline
\end{tabular}

42 | Jurnal Kredo

Vol. 3 No. 1 Oktober 2019 


\begin{tabular}{|c|c|c|c|c|c|c|}
\hline 16. & $\begin{array}{l}\text { Kapan lagi yah } \\
\text { kan, secara } \\
\text { harga murmer }\end{array}$ & & & $\sqrt{ }$ & & $\begin{array}{l}\text { Murah } \\
\text { Meriah }\end{array}$ \\
\hline 17. & $\begin{array}{l}\text { Sebelum } \\
\text { kehabisan cus } \\
\text { langsung order } \\
\text { produk } \\
\text { pilihannya }\end{array}$ & $\sqrt{ }$ & & & & Pergi \\
\hline 18. & $\begin{array}{l}\text { Emak-emak } \\
\text { rempong }\end{array}$ & $\sqrt{ }$ & & & & Repot \\
\hline 19. & $\begin{array}{lr}\text { Kudu jelas dan } \\
\text { detail } & \text { ini } \\
\text { inginnya apa, } \\
\text { semangat }\end{array}$ & $\sqrt{ }$ & & & & Harus \\
\hline 20. & $\begin{array}{l}\text { Sebagai koleksi, } \\
\text { kalau aku jual } \\
\text { kira-kira } \\
\text { padamau kah? } \\
\text { Harga japri aja }\end{array}$ & & & $\sqrt{ }$ & & $\begin{array}{l}\text { Jaringan } \\
\text { Pribadi }\end{array}$ \\
\hline 21. & $\begin{array}{l}\text { Kamu gak } \\
\text { bahagia } \\
\text { makanya } \\
\text { ngusik } \\
\text { kebahagiaan } \\
\text { orang lain. }\end{array}$ & $\sqrt{ }$ & & & & $\begin{array}{l}\text { menggan } \\
\text { ggu }\end{array}$ \\
\hline 22. & $\begin{array}{l}\text { Btw kurang } \\
\text { lengkap } n i\end{array}$ & & & $\sqrt{ }$ & & $\begin{array}{l}\text { By The } \\
\text { Way }\end{array}$ \\
\hline 23. & $\begin{array}{l}\text { Ya Allah pagi- } \\
\text { pagi mewek liat } \\
\text { film ini ... }\end{array}$ & $\sqrt{ }$ & & & & $\begin{array}{l}\text { Menangi } \\
\text { s, sedih, } \\
\text { kecewa }\end{array}$ \\
\hline 24. & $\begin{array}{l}\text { OMG, I cannot } \\
\text { stop my laugh }\end{array}$ & & & $\sqrt{ }$ & & $\begin{array}{l}\text { Oh My } \\
\text { God }\end{array}$ \\
\hline 25. & Cekidoot ... & & $\sqrt{ }$ & & & $\begin{array}{l}\text { Check it } \\
\text { out }\end{array}$ \\
\hline 26. & $\begin{array}{l}\text { Saya lahir dan } \\
\text { dibesarkan di } \\
\text { Batang kuis. } \\
\text { Cung siapa } \\
\text { yang kenal } \\
\text { Batang } \\
\text { kuis? }\end{array}$ & $\sqrt{ }$ & & & & $\begin{array}{l}\text { Kata } \\
\text { panggila } \\
\text { n untuk } \\
\text { yang } \\
\text { kenal } \\
\text { dekat }\end{array}$ \\
\hline 27. & Mupeng & & & $\sqrt{ }$ & & $\begin{array}{l}\text { Muka } \\
\text { Pengen }\end{array}$ \\
\hline 28. & $\begin{array}{l}\text { Dilarang baper } \\
\text { ye }\end{array}$ & & & $\sqrt{ }$ & & $\begin{array}{l}\text { Bawa } \\
\text { Perasaan }\end{array}$ \\
\hline 29. & $\begin{array}{l}\text { Ntar masuk } \\
\text { penjara } \\
\text { sindiran }\end{array}$ & & & & $\sqrt{ }$ & $\begin{array}{l}\text { Gara- } \\
\text { gara }\end{array}$ \\
\hline 30 . & di medsos & & & $\sqrt{ }$ & & $\begin{array}{l}\text { Media } \\
\text { sosial }\end{array}$ \\
\hline 31. & Hbd ya kak... & & & $\sqrt{ }$ & & $\begin{array}{l}\text { Happy } \\
\text { BirthDay }\end{array}$ \\
\hline 32. & $\begin{array}{l}3 \text { dara yang } \\
\text { dulu eksis }\end{array}$ & $\sqrt{ }$ & & & & $\begin{array}{l}\text { Ada, } \\
\text { berkemb } \\
\text { ang }\end{array}$ \\
\hline 33. & $\begin{array}{ll}\text { COD } & \text { anak } \\
\text { bebek.. } & \\
\end{array}$ & & & $\sqrt{ }$ & & $\begin{array}{l}\text { Cash On } \\
\text { Delivery }\end{array}$ \\
\hline
\end{tabular}




\section{Appendix 2}

Table 1.2. SAOS of Millennial Generation in Instagram

\begin{tabular}{|c|c|c|c|c|c|c|c|}
\hline \multirow[b]{2}{*}{ No. } & \multirow[b]{2}{*}{ Discourse } & \multicolumn{5}{|c|}{ Types of SAOS } & \multirow[b]{2}{*}{ Meaning } \\
\hline & & $\begin{array}{l}\text { Fresh and } \\
\text { creative }\end{array}$ & Flippant & Imitative & Acronym & Clipping & \\
\hline 1. & Sepupu gaess & & & $\sqrt{ }$ & & & $\begin{array}{l}\text { Guy or } \\
\text { guys } \\
\text { means } \\
\text { teman, } \\
\text { kawan }\end{array}$ \\
\hline 2. & $\begin{array}{l}\text { Diam bukan } \\
\text { berarti baper }\end{array}$ & & & & $\sqrt{ }$ & & $\begin{array}{l}\text { Bawa } \\
\text { Perasaan }\end{array}$ \\
\hline 3. & $\begin{array}{l}\text { Hayuk } \\
\text { segera } \\
\text { PRSU. }\end{array}$ & $\sqrt{ }$ & & & & & Ayo \\
\hline 4. & $\begin{array}{l}\text { Jangan suka } \\
\text { nyinyir }\end{array}$ & $\sqrt{ }$ & & & & & $\begin{array}{l}\text { Cerewet, } \\
\text { membicar } \\
\text { akan } \\
\text { orang } \\
\text { lain } \\
\text { dengan } \\
\text { kata-kata } \\
\text { pedas }\end{array}$ \\
\hline 5. & $\begin{array}{l}\text { This is my } \\
\text { first } \\
\text { experience } \\
\text { loh. LOL }\end{array}$ & & & & $\sqrt{ }$ & & $\begin{array}{l}\text { Laugh } \\
\text { Out } \\
\text { Loud, } \\
\text { Lots of } \\
\text { Luck, } \\
\text { Lots of } \\
\text { Love }\end{array}$ \\
\hline 6. & $\begin{array}{l}\text { Manfaatkan } \\
\text { waktu sebaik } \\
\text { mungkin } \\
\text { untuk } \\
\text { jenjalan }\end{array}$ & $\sqrt{ }$ & & & & & $\begin{array}{l}\text { Jalan- } \\
\text { Jalan }\end{array}$ \\
\hline 7. & $\begin{array}{l}\text { Gak perlu di } \\
\text { gubris }\end{array}$ & $\sqrt{ }$ & & & & & $\begin{array}{l}\text { Memperd } \\
\text { ulikan }\end{array}$ \\
\hline 8. & $\begin{array}{l}\text { Menuju gila. } \\
\text { Astaga } \\
\text { dragon }\end{array}$ & & $\sqrt{ }$ & & & & $\begin{array}{l}\text { Terpukau } \\
\text { melihat } \\
\text { sesuatu } \\
\text { hal } \\
\end{array}$ \\
\hline 9. & $\begin{array}{l}\text { Itu beli sendii } \\
\text { atau beli } \\
\text { yang couple } \\
\text { \#julid }\end{array}$ & $\sqrt{ }$ & & & & & $\begin{array}{l}\text { Iri hati, } \\
\text { dengki }\end{array}$ \\
\hline 10. & $\begin{array}{l}\text { Padahal } \\
\text { tempat } \\
\text { wisatanya } \\
\text { udah } \\
\text { lumayan } \\
\text { lama tapi } \\
\text { bau sempat } \\
\text { kesini. } \\
\text { \#kudet }\end{array}$ & & & & $\sqrt{ }$ & & $\begin{array}{l}\text { Kurang } \\
\text { Update }\end{array}$ \\
\hline
\end{tabular}

44 | Jurnal Kredo

Vol. 3 No. 1 Oktober 2019 


\begin{tabular}{|c|c|c|c|c|c|}
\hline 11. & $\begin{array}{lr}\text { Coba } & \text { kalau } \\
\text { cuacananya } \\
\text { panas, si } \\
\text { anak pasti } \\
\text { bakalan lebih } \\
\text { betah dan } \\
\text { gak } \\
\text { (BT) }\end{array}$ & & $\sqrt{ }$ & & $\begin{array}{l}\text { Bored } \\
\text { Totally }\end{array}$ \\
\hline 12. & $\begin{array}{l}M C \\
\text { gadungan } \\
\text { cuyy }\end{array}$ & $\sqrt{ }$ & & & $\begin{array}{l}\text { Panggila } \\
n \quad \text { untuk } \\
\text { kawan }\end{array}$ \\
\hline 13. & Curcol ya all & & $\sqrt{ }$ & & $\begin{array}{l}\text { Curhat } \\
\text { Colongan }\end{array}$ \\
\hline 14. & Keburu tuir & $\sqrt{ }$ & & & тиа \\
\hline 15. & $\begin{array}{lr}\text { FYI. } & \text { Cantik } \\
\text { gak } & \text { harus } \\
\text { putih, } & \text { tapi } \\
\text { harus } & \\
\text { perempuan }\end{array}$ & & $\sqrt{ }$ & & $\begin{array}{l}\text { For Your } \\
\text { Informati } \\
\text { on }\end{array}$ \\
\hline 16. & $\begin{array}{l}\text { Tersenyum } \\
\text { dalam } \\
\text { keadaan } \\
\text { sakit. \#gaje }\end{array}$ & & $\sqrt{ }$ & & Gak Jelas \\
\hline 17. & Gws ya & & $\sqrt{ }$ & & $\begin{array}{l}\text { Get Well } \\
\text { Soon }\end{array}$ \\
\hline 18. & Gokil kali & $\sqrt{ }$ & & & Gila \\
\hline 19. & $\begin{array}{lr}\text { Hidup } & \text { itu } \\
\text { jangan } & \text { sok } \\
\text { jaim } & \end{array}$ & & $\sqrt{ }$ & & $\begin{array}{l}\text { Jaga } \\
\text { Image }\end{array}$ \\
\hline 20. & $\begin{array}{l}\text { Jika Tuhan } \\
\text { menjodohkan } \\
\text { mu } \\
\text { denganku, } \\
\text { pacarmu bisa } \\
\text { apa? \#jojoba }\end{array}$ & & $\sqrt{ }$ & & $\begin{array}{l}\text { Jomblo- } \\
\text { Jomblo } \\
\text { Bahagaia }\end{array}$ \\
\hline 21. & $\begin{array}{l}\text { Salfok ama } \\
\text { mobil }\end{array}$ & & $\sqrt{ }$ & & $\begin{array}{l}\text { Salah } \\
\text { Fokus }\end{array}$ \\
\hline 22. & $\begin{array}{l}\text { Keistimewaa } \\
n \text { dari hidup } \\
\text { adalah } \\
\text { menjadi diri } \\
\text { sendiri } \\
\text { \#kuper }\end{array}$ & & $\sqrt{ }$ & & $\begin{array}{l}\text { Kurang } \\
\text { Pergaulan }\end{array}$ \\
\hline 23. & $\begin{array}{l}\text { Bikin orang } \\
\text { gak } \text { kelar- } \\
\text { kelar } \\
\text { ngejurnal }\end{array}$ & $\sqrt{ }$ & & & selesai \\
\hline 24. & Kzl gak sih & $\sqrt{ }$ & & & Kesel \\
\hline 25. & $\begin{array}{l}\text { Lucunya } \\
\text { ketika } \\
\text { seseorang } \\
\text { membencimu } \\
\text { karena } \\
\text { merasa } \\
\text { tersaingi. } \\
\text { Leh uga }\end{array}$ & & & $\sqrt{ }$ & $\begin{array}{l}\text { Boleh } \\
\text { Juga }\end{array}$ \\
\hline 26. & $\begin{array}{l}\text { Ngopi } \\
\text { \#mager }\end{array}$ & & $\sqrt{ }$ & & $\begin{array}{l}\text { Males } \\
\text { Gerak }\end{array}$ \\
\hline
\end{tabular}




\begin{tabular}{|c|c|c|c|c|}
\hline 27. & nongki & $\sqrt{ }$ & & $\begin{array}{l}\text { Nongkron } \\
\mathrm{g}\end{array}$ \\
\hline 28. & pewe & & $\sqrt{ }$ & $\begin{array}{l}\text { Posisi } \\
\text { Wenak } \\
\text { enak) }\end{array}$ \\
\hline 29. & $\begin{array}{l}\text { Belum nih. } \\
\text { Padahal } \\
\text { keknya } \\
\text { rumah dia } \\
\text { beda rata } 2 \\
\text { station sama } \\
\text { gua \#sotoy }\end{array}$ & $\sqrt{ }$ & & Sok tahu \\
\hline 30. & $\begin{array}{l}\text { Rainbow, } \\
\text { unch }\end{array}$ & $\sqrt{ }$ & & $\begin{array}{l}\text { Enak } \\
\text { dong, } \\
\text { asyik } \\
\text { dong }\end{array}$ \\
\hline 31 & $\begin{array}{l}\text { Cantik belum } \\
\text { tentu } \\
\text { tembem, } \\
\text { tembem udah } \\
\text { pasti cantik } \\
\text { \#woles }\end{array}$ & $\sqrt{ }$ & & \\
\hline
\end{tabular}

46 | Jurnal Kredo

Vol. 3 No. 1 Oktober 2019 